\title{
Headmaster Instructional Leadership and Organizational Learning on the Quality of Madrasah and the Quality of Graduates the State Madrasah Aliyah at Jakarta Capital Region
}

\author{
Widhyanti Rosmaniar ${ }^{1} \&$ Shahril Charil bin Hj. Marzuki ${ }^{2}$ \\ ${ }^{1}$ Faculty of Teacher and Education, Sekolah Tinggi Agama Islam Swasta (STAIS) Lantaboer, Jakarta, Indonesia \\ ${ }^{2}$ Universiti Pendidikan Sultan Idris (UPSI), Perak, Malaysia \\ Correspondence: Widhyanti Rosmaniar, Faculty of Teacher and Education, Sekolah Tinggi Agama Islam Swasta \\ (STAIS) Lantaboer, Jakarta, Indonesia. Tel: 62-021-4683-4714. E-mail: yantiros01@gmail.com
}

Received: November 18, 2015

Accepted: January 29, 2016

Online Published: February 22, 2016

doi: 10.5539/hes.v6n1p159

URL: http://dx.doi.org/10.5539/hes.v6n1p159

\begin{abstract}
The purpose of this study is to look closely aspects of instructional leadership, and organizational learning affect the quality of madrasah in improving the quality of graduate the state madrasah aliyah. The experiment was conducted using a quantitative approach with descriptive and inferential methods, in inferential methods used correlation analysis and regression analysis. The process is first conducted analysis of data validity and reliability of data as well as test for normality using the Kolmogorov-Smirnov Test. The study population is the overall teacher the State Madrasah Aliyah at Jakarta Capital Region. The study sample size of 150 teachers. The collecting data about the instrument with research using Likert scale, to obtain data on instructional leadership, organizational learning, quality of madrassah and the quality of graduates. The results of research known that headmaster instructional leadership has a strong and positive relationship with the quality of the madrasah, the quality of graduates, organizational Learnings have strong relationships and positive impact on the quality of madrasah. The quality of graduates and have a reciprocal relationship with a high instructional leadership. It can be concluded that an increasing in the quality of madrasah and the quality of graduates at the school can be done with an increase in instructional leadership and organization of learning in the madrasah. Thus improvement instructional leadership and organizational learning have a positive influence on the improvement of the quality of madrasah and the achievement of the quality of graduates.
\end{abstract}

Keywords: headmaster instructional leadership, organizational learning, the quality of the madrasah, the quality of graduates

\section{Introduction}

Educational success in madrasah is determined by various factors, including basic education, curriculum, teacher or teachers, instructional media, instructional leadership, organizational learning, infrastructure and the relationship between madrasah community, cooperation between the various parties on a common interest in achieving quality education, so that this relationship materialized.

Sallis (2000) says that there are several candidates for the source of quality in education. Among them are: teacher performance, high moral values, perfect test results, the support of parents, the business community and local, abundant resource. The application of the latest technology, strong leadership, and meaningful, shelter and care for pupils and students, and balanced and challenging curriculum.

The presence of a headmaster in the school is urgently needed to bring the school to its intended purpose. Various styles of leadership will characterize the behavior of a leader in performing their duties. Improving the quality of school leadership is strongly influenced by the school principal. The school headmaster as a leader must possess an effective leader. The presence of a headmaster in the school is urgently needed to bring the school to its intended purpose. Various styles of leadership will characterize the behavior of a leader in performing their duties.

Maintenance of the learning process requires good learning organization, management quality learning process this is related to instructional leadership in discharging their duties and functions as leaders. School management 
can work well if the principal madrasah run of good leadership.

Instructional leadership in the school is not fully implemented well. It can be seen from the lack of supervision and monitoring of the learning process in school. This problem occurs when school principals busy with all the daily responsibilities for managing and conducting school that did not have enough time to implement instructional leadership Enueme and Egwunyenga (2008). The results stronge (1988) showed that of all the work to be carried out by the headmaster of the school, only 10 per cent allocated for leadership learning. Principals often place the responsibility to supervise and monitor Officer and Head of Teachers (Hallinger, 2005).

Usman (2001) revealed that the main problem faced by the school principal is incompetent to lead the school in the school. Usman opinion is supported by the results of a study conducted by Slamet (2000) says that the low utilization of human resources in the scope of the school is basically due to the pattern of thinking, organizing, and analyzing education is not systematic. Within the framework of management. School principals have two big role in achieving the goals the school, the school manager as well as school leaders. The second role is inherent in a school headmaster (Sergiovani \& Starratt, 1993). In the madrassas to produce a good quality of learning takes an organized learning process, learning organization is needed as plans to produce a quality education. Hillinger (1985) and Murphy (2006) found that there were only three instructional leadership functions, i.e., monitor student progress, maintaining high visibility, and the development and strengthening academic standards have a positive correlation with academic achievement.

Hallinger and Murphy (1987) have compiled a list of eleven instructional leadership characteristics are grouped into three main dimensions, namely clarifying and defining the goals of the school's goals include drafting and presenting and disseminating the goals of the school. The second dimension is to manage the learning program or learning accounting supervision and assessment, coordinate and monitor student progress on curriculum. The third dimension is to create or promote a positive learning climate control includes actions such as learning time and learning, culture and staff professional development, maintaining visibility, provide incentives to teachers, stressing academic excellence and provide incentives to students.

Without the learning organization in schools, possible learning activities will be better. The quality and success of learning is strongly influenced by the ability of teachers and teachers in organizing learning accuracy to be implemented. The learning process requires good learning organizer, has the management undertaken by teachers and overseen by a supervisor oversee madrasah teachers in schools in order to process the learning goes well.

This school has a quality learning process led by principals who exercise instructional leadership. The school can create a good quality school. School quality is reflected in the effectiveness and efficiency of the learning process is carried out in schools, effective schools have based on various characteristics, including research: (A) a strong instructional leadership; (B) high expectations of student achievement; (C) the orderly learning environment and comfortable; (D) an emphasis on basic skills; (E) continuous monitoring of student progress; and (F) school clearly formulated goals (Davis \& Thomas, 1989).

Improving the quality of madrasah depending on headmaster instructional leadership, as well as the organization of good learning, carrying out various activities in the learning process in madrasah need for supervision and intervention of the head of the madrasah, supervising teachers in the implementation of the learning process reduce the possibility of problems in learning so that it will produce a good quality of learning, it is seen from the quality of madrasah graduates.

The purpose of this study is to look closely aspects of headmaster instructional leadership, and organizational learning affect the quality of madrasah in achieving the quality of graduates, in particular the objectives to be achieved in this investigation is to analyze the headmaster instructional leadership and learning organizations with the quality of the madrasah and quality of madrasah graduates.

The purpose of the study is: 1) review stage headmaster instructional leadership, organizational learning, the quality of madrasah and the quality of graduates; 2) analyze the relationship the headmaster instructional leadership with the quality of madrasah and the quality of graduates; 3) analyze the relationship the organizational learning with the quality of madrasah and the quality of graduates; 4) analyze the relationship of the quality of madrasah with the quality of graduates; 5) analyze the relationship of headmaster instructional leadership and learning organizations with the quality of madrasah; 6) analyze the relationship of headmaster instructional leadership and learning organizations with the quality of graduates.

Questions fostered studies aim to ensure that all study objective can be achieved. For that purpose, this study suggests six major research questions is: 1) how the stage of headmaster instructional leadership, the learning 
organization, quality of madrasah and the quality of graduates; 2) how is the relationship between the headmaster instructional leadership with the quality of madrasah and the quality of graduates; 3 ) how is the relationship between the organizational learning with the quality of madrasah and the quality of graduates?; 4) how is the relationship between the quality of madrasah with the quality of graduates; 5) how is the relationship between the headmaster instructional leadership and learning organizations with the quality of madrasah; 6) how is the relationship between the headmaster instructional leadership and learning organizations with the quality of graduates.

Hypothesis of the study will be tested with correlation and regression analysis. Study hypotheses constructed to ensure that all study objectived can be achieved. The purpose of the proposed study, to be achieved are as follows: Hypothesis I: There is a relationship between the headmaster instructional leadership with the quality of madrasah and the quality of graduates. Hypothesis II: There is a relationship between the organizational learning with the quality of madrasah and the quality of graduates. Hypothesis III: There is a relationship between the quality of madrasah and the quality of graduates. Hypothesis IV: There is a relationship between the headmaster instructional leadership, organizational learning with the quality of madrasah. Hypothesis V: There is a relationship between the headmaster instructional leadership, organizational learning with the quality of graduates.

\section{Research Methods}

The design of this study used quantitative research methods descriptive and inferential. According to Yin (1994) research design considered a logical connection between the data to be collected and the conclusions of the study to the research questions set out in the study. A descriptive design was used to obtain a clear picture of mean, median, mode, and standard deviation. Data descriptive studies usually collected by administering a questionnaire, interview respondents, observe events or analyze documents (Dalen, 1979). Interpretation of descriptive analysis as expressed by Nunnally (1978), namely: 1.01 to 2.00 Mean scores (low); 2.01 to 3.00 (simple low); 3.01 to 4.00 (simple high); 4.01 to 5.00 (high). Inferential analysis in research used correlation and regression analysis. Correlation analyzes were performed using Product Moment correlation. The use of regression is to determine the level of the relationship and the influence of independent variables on the dependent variable. Normality test is carried out in advance of the Inferential analysis. Normality test used the One Sample Kolmogorov-Smirnov Test, The test sample is to assess whether samples taken from a population with normal distribution.

The study is limited to government schools in the city of Jakarta. To ensure a smooth process of data collection, research will be conducted for teachers who work in schools. The determination of sample size in this study is based on the opinions Arikunto (2004) saying that for just about then when his study is the research population, then when the subject can be taken between $10-15 \%$ and $20-25 \%$ or more. In this study, researchers took a sample of $15 \%$ of the total population, the sample is 150 teachers to be sampled in the study.

For the purposes of this study, the questionnaire is used as a primary research tool for gathering information about of the headmaster instructional leadership, organizational learning in school on the quality of madrasah associated with the quality of graduates. Data obtained from questionnaires headmaster instructional leadership, organizational learning and the quality of madrasah which is connected with the quality of graduates. This is to see the relationship headmaster instructional leadership, organizational learning and the quality of madrasah linked to the quality of graduates. The researchers used questionnaires as instruments to collect quantitative data. The questionnaire is an ideal tool for obtaining information relating to the facts, beliefs, noticing, desire and so on of the large sample size scattered to reduce the expense, time and energy (Burn, 1995; Handler, 1993; Gay, 1992). Respondents need to respond to the statement submitted by the rounding of the numbers on the scale provided. Feedback for each statement is provided in every room.

Before the research conducted, testing instrument used instruments measurement and research data normality. Instruments measuring are used validity and reliability, while normality data used the Kolmogorov-Smirnov analysis. Validity Test data shows that the overall instrument items totaling 40 items be declared invalid in the range of 0.497-0.932 and can be used to step up research. Reliability test in this study using Cronbach Alpha of the result, the reliability test of 0.988 , indicating that the high reliabitas the instrument otherwise reliable (dependable, reliable or consistent).

Furthermore, normality test aims to determine whether the data has spread normal data or normal distribution. Although there are is several ways to test the normality of the data but in this study using the One Sample Kolmogorov-Smirnov Test. From the research value of the normality test headmaster instructional leadership variable has a value of normality test is $=0.461$, organizational learning has value is $=0.093$, variable quality of 
madrasah has a value is $=0.069$ and variable quality of graduate has a value is $=0649$. Due to limited asymp value Sig. (2-tailed) fourth assessment variable is larger than the value of the significant level of 0.05 , then all the data were normally distributed, and can be used for further research studies.

\section{Research Result}

\subsection{Descriptive Analysis}

Descriptive analysis is used to answer the first research question is to know the stage of headmaster instructional leadership, the stage of the organizational learning, quality of madrasah and the quality of graduates. Adaptive research shows headmaster instructional leadership has a mean value is $=36.77$, standard deviation value is $=$ 6.535 , the median value is $=37$, the value of variance is $=42.704$, the value of kurtosis and skewness is $=-0.795$, -0.185 . Stage learning organization values mean is $=36.83$, standard deviation value is $=6.472$, the median value is $=37$, the value of variance is $=41.885$, the value kurtosis is $=-1.2001$ and value skewness is $=-0.103$. Madrasah quality stage has a mean value is $=36.133$, the standard deviation value is $=6.43884$, the median value is $=37$, the value of variance is $=41.459$, the value of kurtosis and skewness is $=-0.712,-0.481$, the stage of the quality of graduates has a mean value is $=36.76$, standard deviation value is $=7.6883$, median value is $=$ 37 , variance value is $=59.1098$, kurtosis value is $=-0.8395$ and skewness value is $=-0.20995$. Study data were analyzed used descriptive statistics are shown in Table 1.

Table 1. Descriptive analysis variable headmaster instructional leadership, organizational learning, quality of madrasah and quality of graduates

\begin{tabular}{|c|c|c|c|c|c|c|c|}
\hline \multicolumn{2}{|c|}{ Variable } & \multirow{2}{*}{$\begin{array}{l}\text { Mean } \\
36.76667\end{array}$} & \multirow{2}{*}{$\begin{array}{l}\text { Standar } \\
\text { Deviation }\end{array}$} & \multirow{2}{*}{$\begin{array}{l}\text { Variance } \\
42.70358\end{array}$} & \multirow{2}{*}{$\begin{array}{l}\text { Median } \\
37\end{array}$} & \multirow{2}{*}{$\begin{array}{c}\text { Skewness } \\
-0.18489\end{array}$} & \multirow{2}{*}{$\begin{array}{c}\text { Kurtosis } \\
-0.79541\end{array}$} \\
\hline 1 & Instructional Leadership & & & & & & \\
\hline 2 & Organizational Learning & 36.83333 & 6.471846 & 41.88479 & 37 & -0.10268 & -1.20064 \\
\hline 3 & Quality of Madrasah & 36.13333 & 6.438836 & 41.45861 & 37 & -0.48061 & -0.71149 \\
\hline 4 & Quality of Graduates & 36.76 & 7.68829 & 59.1098 & 37 & -0.20995 & -0.83949 \\
\hline
\end{tabular}

$\mathrm{N}=150$.

Table 1 shows that headmaster instructional leadership, organizational learning, the quality of madrasah and the quality of graduates has value stages high. The results can be seen that the headmaster has a instructional leadership in madrasah is high, by providing a wide range of encouragement and motivation to teachers to apply their learning well, it is also supported by the results of studies showing that there is a learning organization at the school has a high value, so it will show the high quality of the madrasah and the quality of graduates.

\subsection{Inferential Analysis}

Inferential analysis was used to analyze the hypothesis of research include correlation analysis, regression analysis. Correlation analysis was used to analyze the hypothesis number 1,2 and 3, the regression analysis was used to analyze the hypothesis number 4 and 5 .

\subsection{Correlation Analysis}

Correlation analysis is useful for determining the relationship between variables. In this study the correlation calculation using the formula Pearson's Product Moment with alpha of 0.05 and test sig. two-tailed. Results of analysis can be seen in Table 2 . 
Table 2. Correlation analysis headmaster instructional leadership and organizational learning with quality of madrasah and the quality of graduates

\begin{tabular}{llll}
\hline & & Quality Madrasah & Quality of Graduates \\
\hline Headmaster & Instructional Pearson Correlation & $.965^{* *}$ & $.978^{* *}$ \\
& Sig. (2-tailed) & .000 & .000 \\
& $\mathrm{~N}$ & 150 & 150 \\
Organizational Learning & Pearson Correlation & $.971^{* *}$ & $.980^{* *}$ \\
& Sig. (2-tailed) & .000 & .000 \\
& $\mathrm{~N}$ & 150 & 150 \\
Quality of Madrasah & Pearson Correlation & 1 & $.972^{* *}$ \\
& Sig. (2-tailed) & & .000 \\
& $\mathrm{~N}$ & 150 & 150 \\
\hline
\end{tabular}

** Correlation is significant at the 0.01 level (2-tailed).

Table 2 above shows that through the analysis of the correlation looks relationship between the headmaster instructional leadership with the quality of madrasah $(r=0.965)$, the relationship between the headmaster instructional leadership with the quality of graduates $(r=0.978)$, relationship between the organizational learning with quality of madrasah $(r=0.971)$, relationship between the organizational learning with the quality of graduates $(\mathrm{r}=0.980)$, and relationship between the quality of madrasah with the quality of graduates $(\mathrm{r}=$ 0.972). Thus seen overall variables have a strong relationship. From the research shows that the hypothesis 1,2 , and 3 in this study had a high relationship, specifically it can be said that the headmaster instructional leadership have high relationship to the quality of madrasah, and to the quality of graduates, organizational learning has a high relationship to quality madrasah and the quality of graduates, and the quality of the madrasah have a high relationship to the quality of graduates.

\subsection{Regression Analysis}

3.4.1 Relationship between the Headmaster Instructional Leadership and Organizational Learning with Quality Madrasah

Hypotheses to 4 is relationship between headmaster instructional leadership and organizational learning with quality madrasah. Headmaster instructional leadership and organizational relationship with the quality of madrasah study used regression analysis. Regression analysis looks determination coefficient of 0.945 or $94.5 \%$. This value indicates the magnitude of the effect of variable headmaster instructional leadership and learning organizations with the quality of madrasah is $94.5 \%$ or 0.945 . To determine the regression analisis headmaster instructional leadership and organizational learning with quality of madrasah can be seen in Table 3 .

Table 3. Determination coefficient of headmaster instructional leadership and organizational learning and quality of madrasah

\begin{tabular}{lllll}
\hline Model & $\mathrm{R}$ & R Square & Adjusted R Square & Std. Error of the Estimate \\
\hline 1 & $.972^{\mathrm{a}}$ & .945 & .944 & 1.519 \\
\hline
\end{tabular}

a. Predictors: (Constant), organizational learning, headmaster instructional leadership

Table 3 shows the results of determinacy coefficient, the table shows the effect of each variable causal headmaster instructional leadership and organizational learning with the quality of madrasah is high. 
Table 4. Regression analysis headmaster instructional leadership and organizational learning and quality of madrasah

\begin{tabular}{|c|c|c|c|c|c|c|c|}
\hline \multirow[b]{2}{*}{ Model } & & & \multicolumn{2}{|c|}{ Unstandardized Coefficients } & \multicolumn{2}{|c|}{$\begin{array}{l}\text { Standardized } \\
\text { Coefficients }\end{array}$} & \multirow[b]{2}{*}{ Sig. } \\
\hline & & & $\mathrm{B}$ & Std. Error & Beta & $\mathrm{t}$ & \\
\hline \multirow[t]{3}{*}{1} & (Constant) & & .511 & .719 & & .711 & .478 \\
\hline & $\begin{array}{l}\text { Headmaster } \\
\text { Leadership }\end{array}$ & Instructional & .305 & .106 & .310 & 2.877 & .005 \\
\hline & Organization & Learning & .663 & .107 & .666 & 6.187 & .000 \\
\hline
\end{tabular}

a. Dependent Variable: Quality of Madrasah.

From Table 4 shows the results in the column shows the value Beta variable headmaster instructional leadership to variable quality of madrasah is $\beta=0.310$ and the variable the organizational learning to variable quality of madrasah is $\beta=0.666$. The relationship of these two variables is significant because the headmaster instructional leadership and the organizational learning has the value of Sig. $<0.05$. To determine the linearity of a relationship between variables headmaster Instructional leadership and organizational learning and quality of madrasah can be seen in Table 5 .

Table 5. Linearity relationship headmaster instructional leadership and organizational learning with the quality of madrasah

\begin{tabular}{lllllll}
\hline Model & & Sum of Squares & df & Mean Square & F & Sig. \\
\hline 1 & Regression & 5838.297 & 2 & 2919.148 & 1265.690 & $.000^{\mathrm{a}}$ \\
& Residual & 339.036 & 147 & 2.306 & & \\
& Total & 6177.333 & 149 & & & \\
\hline
\end{tabular}

a. Predictors: (Constant), headmaster instructional leadership and organizational learning.

b. Dependent Variable: quality of madrasah

Table 5 shows the linearity of the model to test the causal chain, has provisions value Sig. $<0.05$, so that hypotheses received, that is the linear causal chain model. It can be said that there is a relationship between the headmaster instructional leadership and organizational learning on the quality of madrasah, this suggests that the higher the headmaster instructional leadership owned and organizational learning that will either increase the quality of madrasah.

3.4.2 Relationship between the Headmaster Instructional Leadership, Organizational Learning and Quality of Madrasah with the Quality of Graduates

Hypotheses to 5 is relationship between the headmaster instructional leadership, organizational learning and the quality of madrasah with the quality of graduates, for analysis this hypotesis used regression analysis, regression analysis looks value determination coefficient is 0.971 or $97.1 \%$. This value indicates the magnitude of the relationship of variable headmaster instructional leadership, organizational learning and the quality of madrasah with the quality of graduates is $97.1 \%$ or 0.971 . To determine the regression analysis the headmaster instructional leadership, organizational learning and the quality of madrasah with the quality of graduates can be seen in Table 6. 
Table 6. Determination coefficient relationship between the headmaster instructional leadership, organizational learning and quality of madrasah with quality of graduates

\begin{tabular}{lllll}
\hline Model & $\mathrm{R}$ & R Square & Adjusted R Square & $\begin{array}{l}\text { Std. Error of the } \\
\text { Estimate }\end{array}$ \\
\hline 1 & $.985^{\mathrm{a}}$ & .971 & .970 & 1.322 \\
\hline
\end{tabular}

a. Predictors: (Constant), Quality of Madrasah, Headmaster Instructional Leadership, Organizational Learning

Table 6 shows the results of determinacy coefficient, the table shows the effect of each variable causal headmaster instructional leadership and organizational learning and quality of madrasah with the quality of madrasah is high.

Table 7. Regression analysis of headmaster instructional leadership, organizational learning and quality of madrasah with quality of graduates

\begin{tabular}{|c|c|c|c|c|c|c|}
\hline \multirow[b]{2}{*}{ Model } & & \multicolumn{2}{|c|}{ Unstandardized Coefficients } & \multicolumn{2}{|c|}{$\begin{array}{l}\text { Standardized } \\
\text { Coefficients }\end{array}$} & \multirow[b]{2}{*}{ Sig. } \\
\hline & & B & Std. Error & Beta & $\mathrm{t}$ & \\
\hline \multirow[t]{4}{*}{1} & (Constant) & -6.390 & .627 & & -10.188 & .000 \\
\hline & $\begin{array}{l}\text { Instructional } \\
\text { Leadership }\end{array}$ & .385 & .095 & .327 & 4.058 & .000 \\
\hline & $\begin{array}{l}\text { Organizational } \\
\text { Learning }\end{array}$ & .424 & .105 & .357 & 4.055 & .000 \\
\hline & Quality of Madrasah & .370 & .072 & .310 & 5.147 & .000 \\
\hline
\end{tabular}

a. Dependent Variable: Quality of Graduates

Table 7 shows the regression analysis between the variables of the table shows the effect of each variable causal headmaster instructional leadership, organizational learning and the quality of madrasah with the quality of graduates. Based on regression analysis, it shows the effect of each variable causal headmaster instructional leadership, organizational learning and the quality of madrasah with the quality of graduates. In the Beta column shows the relationship variable headmaster instructional leadership to variable quality of graduates $\beta=0.327$, the relationship of variable organizational learning to variable quality of graduates $\beta=0.357$ and the relationship of variable quality of madrasah to variable quality of graduates $\beta=0.310$. The third relationship of these variables on the quality of graduates is significantly because the Sig. $<0.05$. To determine the linearity of a relationship between variable headmaster instructional leadership, organizational learning and the quality of madrasah with the quality of graduates can be seen in Table 8 .

Table 8. Linearity relationship headmaster instructional leadership, organizational learning and quality of madrasah and quality of graduates

\begin{tabular}{lllllll}
\hline Model & & Sum of Squares & df & Mean Square & F & Sig. \\
\hline 1 & Regression & 8552.065 & 3 & 2850.688 & 1630.273 & $.000^{\mathrm{a}}$ \\
& Residual & 255.295 & 146 & 1.749 & & \\
& Total & 8807.360 & 149 & & & \\
\hline
\end{tabular}

a. Predictors: (Constant), Quality of Madrasah, Headmaster Instructional Leadership, Organizational Learning

b. Dependent Variable: Quality of Graduates 
Table 8 shows to test the linearity of the causal chain model, has provisions value $\mathrm{Sig}<0.05$, that is the linear causal chain model. Based on the Table 8 value Sig. 0.000 , this means the value of Sig. $<0.05$, so the hypothesis 5 in this study which states that there is a relationship between the headmaster instructional leadership, organizational learning and quality of madrasah with quality of graduates is verified.

\section{Discussion of Results}

Improved quality of madrasah and the quality of graduates is the main goal in the madrasah. The improvement of education can be seen from the high quality of education in the madrasah, as well as graduates produced. The survey results revealed that the headmaster instructional leadership and organizational learning has a high relationship to the quality of madrasah and the quality of graduates. Improvement and development of quality of madrasah and the quality of graduates can be done with improvements in headmaster instructional leadership and organizational learning, if the headmaster instructional leadership and organizational learning in schools is low, can lead to low quality of the madrasah and the quality of graduates at the school.

To be able to produce quality, according to Slamet (1999) there are four business fundamental that must be done in an educational institution, namely: creating a situation of "win-win" (win-win) and not the situation "zero-sum" between the parties with an interest in educational institutions (stakeholders); The need for cultivated their intrinsic motivation to everyone involved in the process of grabbing quality; Every leader should be a process-oriented and long-term results; In mobilize all educational institutions the ability to achieve defined quality, must be developed for cooperation between the elements of the process actors achieve quality results.

To achieve quality madrasah graduates and high quality learning requires good leadership, Green (1988) confirms the leading role principals that is a learning leader. Hoyle (1987) found that proficiency encompass teaching principals in four cases that is curriculum and instruction, assessment, supervision and development of staff. The most important factor that determines a person considered an effective school leader or not measured on their ability to perform duties as leaders of learning (Buckner, 2011; Fullan, 2002; Leithwood \& Levin, 2010; Hallinger, 2008, 2011; Ishak, 2004).

Increased instructional leadership can improve the learning process in schools. The learning process was carried out by teachers, this research is in line with research conducted by Koehler (2010) conducted an experimental study to see the effect of the consulting team teaching. Teachers teaching efficacy which demonstrate leadership through teaching implementation consultancy. Team teaching shows significant improvement to the efficacy of teaching teachers, and thus have a leadership role instrucsional high in achievement of high or low quality of education in schools. The learning process requires good management of teachers, teachers who are able to manage the learning process can make the learning process more effective and efficient in achieving the goal of education.

Improved learning organization, improving the professionalism of teachers in achieving educational goals, it is directly related to the quality of the learning process itself, teachers who have the ability to teach will be able to manage the process of learning that is aligned with the goals of education, and the achievement of student achievement in school. Graczewski, Knudson, and Holtzman (2009) found a significant positive relationship between goal setting comprehensive school to the professional growth of effective teachers focused on teaching content and curriculum. Teacher requires basic competencies to become an educator. Teaching competence of teachers should include content knowledge, skills and positive attitudes (Good \& Mulryan, 1990).

Carrol (1963) said that effective teaching by teachers affected by five factors: attitude, ability to understand the teaching, the teacher perseverance, opportunity and quality teaching. Process quality learning can take place when a teacher can manage the learning process itself. Shahril (2005) also emphasized that teacher with effective teaching competence to teach in accordance with the appropriate level of ability and the ability of their students. Therefore in order to improve the quality of madrasah and the quality of graduates, learning organization became one focus of improvement and development, if it wants a high quality education in madrasah.

\section{Conclusion}

Instructional leadership in research has direct effects on the quality of graduate school and the quality of the relationship is very strong, positive and significant. Similarly, the Learning Organization to give direct effect on the quality of the school and the quality of graduates. Headmaster instructional leadership, organizational learning, quality of madrasah and and quality of graduates has the value of stages are good, quality improvement and the quality of graduate school implemented with increased headmaster instructional leadership and organizational learning in school.

The principal can perform the task as an instructional leader can influence the direction and outcome of the 
learning process in schools, this is due to a larger role of a headmaster in creating a good learning process, the support and attention of the principal motivating and moral support to teachers in managing the learning process in schools as an effort to improve the quality of education. Managing the learning process will not be achieved if only done by a teacher, another element that takes the role of a principal as instructional leader, in other words, whether good or bad quality and the quality of graduate school in the school, depending on the seriousness and the ability of a headmaster in improving instructional leadership at the school, in the absence of instructional leadership at the school will not be any improvement in the quality of school education, which resulted in lower quality of graduate school. The very important for a headmaster to improve their capabilities and skills in conducting instructional leadership at the school.

\section{References}

Arikunto, S. (2004). Prosedur Penelitian: Suatu pendekatan Praktek. Bandung: Rineka Cipta.

Buckner, K. R. (2011). Leadership practices of female principals. Capella University.

Burn, R. B. (1995). Introduction to Research Methods. Melbourne: Longman.

Carroll, J. (1963). A model of school learning. Teachers College Record, 64, 723-773.

Dalen Van, D. B. (1979). Understanding Educational Research an Introduction. New York: Mc Grow-Hill, Inc.

Davis, \& Thomas. (1989). Effective schools and effective teachers. Needham Heights: Allyn and Bacon.

Enueme, P., \& Egwunyenga, J. (2008). Principals' Instructional Leadership Roles and Effect on Teachers' Job Performance: A Case Study of Secondary Schools in Asaba Metropolis. Kamla Raj. J. Soc. Sci., 16(1), 13-17. Delta State, Nigeria.

Fullan, M. (2002). The Change Leader. Educational Leadership, 59(8), 16-20.

Gay, L. R. (1992). Educational Research: Competencies for Analysis and Application (4th ed.). New York: Macmillan Publishing Company.

Good, T. L., \& Mulryan, C. (1990). Teacher ratings: A call for teacher control and self evaluation. In Dlm. J. Millman, \& L. Darling-Hammond (Eds.), Assessing: Elementary and secondary school teachers (pp. 191-215). Newbury Park, CA: Sage.

Graczewski, C., Knudson, J., \& Holtzman, D. J. (2009). Instructional leadership in practice: What does it look like, and what influence does it have? Journal of Education for Students at Risk (JESPAR), 14(1), 72-96. http://dx.doi.org/10.1080/10824660802715460

Green, J. E. A. (1977). The Perception of Leader Behaviour of Elementary School Principals and it is Relationship with Educational Innovations. Universiti Michigan, Tidak diterbitkan.

Hallinger, P. (2005). Instructional leadership and the school principal: A passing fancy that refuses to fade away. Leadership and Policy in Schools, 4, 221-239. http://dx.doi.org/10.1080/15700760500244793

Hallinger, P. (2008). Methodologies for studying school leadership: A review of 25 years of research using the Principal Instructional Management Rating Scale. Paper presentation at the annual meeting of the American Educational Research Association. New York.

Hallinger, P. (2011). A review of three decades of doctoral studies using the Principal Instructional Management Rating Scale: A lens on methodological progress in educational leadership. Educational Administration, 47(2), 271-306. http://dx.doi.org/10.1177/0013161X10383412

Hallinger, P., \& Murphy, J. (1985). Assessing the instructional management behavior of principals. Elementary School Journal, 86(2), 217-247. http://dx.doi.org/10.1086/461445

Hallinger, P., \& dan Murphy, J. (1987). Assessing the Instructional Leadership Behavior of Principals. Elementary School Journal, 23, 34-45.

Handler, M. G. (1993). Preparing new teachers to use computer technology: Perceptions and suggestions for teacher educators. Computers Education, 20(2), 147-156. http://dx.doi.org/10.1016/0360-1315(93)90082-T

Hoyle, J. R. (1987). The AASA Model for Preparing Scholl Leaders. In D. J. Murphy dan, \& P. Hallinger (Eds.), Approaches to Adminidtrative Training in Education. New York: State University of New York Press.

Ishak, S. (2004). Sekolah berkesan: Amalan-amalan dalam pengurusan dan pendidikan. Jurnal Pengurusan dan Kepimpinan Pendidikan, 14(2), 1-21.

Koehler, J. R. (2010). An experimental evaluation of the effect of Instructional Consultation Teams on teacher 
efficacy: A multivariate, multilevel examination. Disertasi PhD, University of Maryland, College Park.

Koehler, J. R. (2010). An experimental evaluation of the effect of Instructional Consultation Teams on teacher efficacy: A multivariate, multilevel examination. Disertasi PhD, University of Maryland, College Park.

Leithwood, K., \& Levin, B. (2010). Understanding how leadership influences student learning. International Encyclopedia of Education. Oxford, UK: Elsevier.

Marzuki, S. C. M. (2005). Amalan pengajaran guru berkesan: Kajian di beberapa sekolah menengah Malaysia. Seminar Penyelidikan Pendidikan Maktab Perguruan Batu Lintang, Batu Lintang.

Murphy, J. (2006). Preparing School Leaders: Defining a Research and Action Agenda. Lanham, MD: Rowman \& Littlefield Education.

Sallis, E. (2006). Manajemen mutu pendidikan. Yogyakarta: IRCSoD.

Santoso, S. (2001). Konsep dan Aplikasi dengan SPSS. Jakarta: PT. Elex Media Komputindo.

Sergiovanni, T., \& Starratt, R. (1993). Supervision: A redefinition. New York: McGraw-Hill, Inc.

Slamet, M. (1999). Filosofi Mutu dan Penerapan Prinsip-Prinsip Manajemen Mutu Terpadu. Bogor: IPB.

Slamet, P. H. (2000). Karakteristik Kepala Sekolah Tanggung. Jurnal Pendidikan dan Kebudayaan, 21(IV), 319-333.

Stronge, J. H. (1988). A position in transition? Principal, 67(5), 32-33.

Usman, M. U. (2001). Menjadi Guru Profesional. Bandung: Remaja Rosdakarya.

Yin, R. K. (1994). Case study research: Design and methods (2nd ed.). Newbury Park, CA: Sage Publications.

\section{Copyrights}

Copyright for this article is retained by the author, with first publication rights granted to the journal.

This is an open-access article distributed under the terms and conditions of the Creative Commons Attribution license (http://creativecommons.org/licenses/by/3.0/). 